\title{
«Studien er et eneste langt Angrep»
}

\section{| 1929 utga den unge medisinstuden- ten Trygve Braatøy (1904-53) boken Livets cirkel. Bidrag til en analyse av Knut Hamsuns diktning. Det var den første psykoanalytiske studien i norsk litteratur.}

Sommeren 1929 sendte Braatøy manuskriptet til Hamsun. Han spurte om dikteren kunne anbefale det utgitt, ettersom forlaget ikke ville utgi det av hensyn til ham (1). Dette var Braatøys første bok (2). Han var 25 år gammel og sikkert spent på hva mesteren, som hadde programfestet nervediktning (3), ville uttale. Responsen var lite oppløftende:

\section{Hr. Braatøy}

De kunde ha sparet Dem selv og mig for at sende mig Manuskriptet, jeg loeser intet av det som skrives om mig. Naar Forlagene ikke vil utgi Deres Studie av Hensyn til mig saa er det bare et Paaskud, selv om Studien er et eneste langt Angrep. En anden sak er det at et mere kritisk eller filosofisk Arbeide om mit Forfatterskap er uscelgelig.

Deres arbødige

Knut Hamsun

\section{En psykoanalytisk studie}

Braatøys enke, Sigrid Braatøy (f. 1917),

har fortalt at «Min mann lo av brevet, for

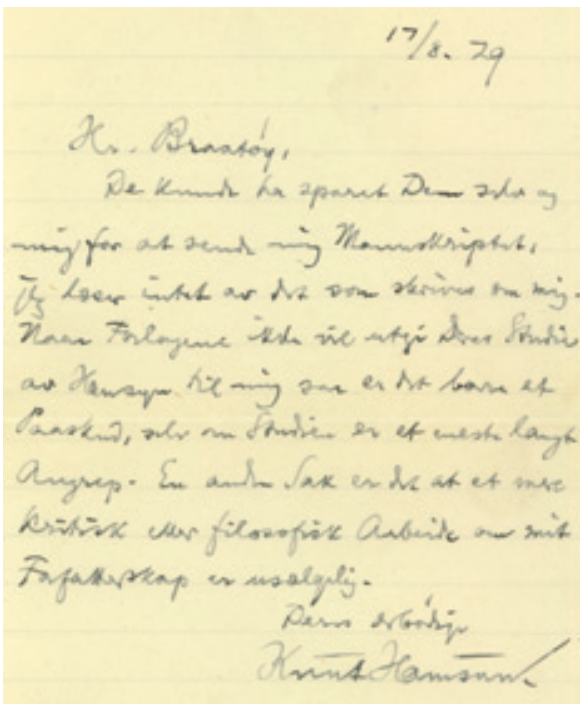

Faksimile av Knut Hamsuns brev til Trygve Braatøy fra 1929. Originalen er i dag i artikkelforfatterens eie pakken hadde vært åpnet» (4). Hamsun skrev at han ikke hadde lest manuskriptet, men karakteriserte det like fullt som et angrep.

Hamsun hadde formodentlig bladd i det og kanskje latt seg fornærme allerede av de to første kapitteloverskriftene: Usikkerhet og Øynene. I god psykoanalytisk tradisjon søkes forklaringene på Hamsuns skrivekunst i egenskaper eller tilbøyeligheter med motsatt fortegn. Genialiteten skyldes usikkerhet, mindreverdighetsfølelse og lyte (nærsynthet). Det er kanskje til å bli fornærmet av for noen hver.

Braatøy karakteriserte Hamsun. Bare det, kan man tenke seg, fikk dikteren til å reise bust. Han gikk tidlig ut mot slikt. Mest kjent er hans uttalelser mot Ibsen på foredragsturneen i 1881. Han hadde bare forakt til overs for Ibsens typetegninger: «Er der nogen Mand i vor Literatur som har skabt «Karakterer» i al deres stejle Enkelhed, saa er det ham. (...) Apparater, som har staaet frem og repræsenteret Begreber og Ideer» (5). Men det var nesten 50 år tidligere. Etter det kom Sult (1890), deretter Mysterier (1892), hans mest desperate bok, med Nagel som karakterløs hovedperson.

Hamsun hadde fylt 70 år noen dager før han skrev svarbrevet til Braatøy. Hans interesse for psykologisk litteratur hadde tatt en dreining - nervediktning, slik han bedrev det i yngre år, var lagt på hyllen. Hamsun var derfor kanskje ikke interessert i Braatøys analyse i det hele tatt og kan ha ment at den ikke hadde interesse for andre heller.

Brevet kan imidlertid ha hatt sin innflytelse på forleggeren, som utga boken senere samme år (4).

\section{Braatøys beste bok?}

Trygve Braatøy gikk frimodig til verks med å karakterisere dikteren med bakgrunn i romanfigurene. Psykoanalysen legitimerer en slik tilnærming, skrev han.

Braatøy ble tidlig engasjert i Freuds og Adlers psykoanalytiske ideer (6), og Livets cirkel er den første psykoanalytiske litteraturstudie i Norge. Den vakte betydelig oppsikt (7) og er blitt sett på som en av Braatøys beste bøker. Men forfatteren ble også kritisert for å utgi en slik bok mens Hamsun fremdeles var i live (8).

Fem år senere utga Braatøy en essaysamling med et tillegg til Livets cirkel (9). Her mente han at hans tidligere hypoteser om Knut Hamsuns diktning, som Hamsuns sterke binding til moren og den uløste ødipale konflikt, var blitt bekreftet i dikterens senere bøker (8). «Det sentrale i «Livets Cirkel» er påstanden om at Hamsun er bundet til sin egen barndom på en slik måte at han aldri kan rive sig løs. Hans innerste drøm er drømmen om å være morens elsker,» skrev Braatøy $(9$, s. 18).

Dette tillegget er med i annenutgaven av Livets cirkel, som kom ut i 1954, året etter Braatøys altfor tidlige død. Sigurd Hoel (1890-1960) skrev forordet, og boken ble også oversatt til dansk.

I 1979, 50 år etter at den ble utgitt første gang, ble Livets cirkel utgitt på nytt. Kanskje ikke for siste gang?

\section{Terje Øiesvold}

terje.oiesvold@nlsh.no

Nordlandssykehuset

Bodø

og

Universitetet i Troms $\varnothing$

Tromsø

Oppgitte interessekonflikter: Ingen

\section{Litteratur}

1. Kolloen IS. Hamsun. Erobreren. Oslo: Gyldendal, 2004: 71-3.

2. Braatøy T. Livets cirkel. Bidrag til analyse av Knut Hamsuns diktning. Oslo: Fabritius \& Sønners Forlag, 1929.

3. Hamsun K. Fra det ubevidste Sjæleliv. Samtiden 1890: 1: 325-34.

4. Næss HS. Knut Hamsuns brev. Bd. 5: 1925-1933. Oslo: Gyldendal, 1999: 259-60.

5. Hamsun K. Norsk Literatur. I: Hamsun T, red. Paa Turné: tre foredrag om litteratur. Oslo: Gyldendal, 1960

6. Haugsgjerd S. Trygve Braatøy - psykoanalytiker, kulturanalytiker, folkeopplyser. I: Øiesvold T, red. Engasjement og kunnskap. Tekster i norsk psykiatri. Oslo: Tidsskrift for Den norske legeforening 2007: 19-20

7. Koch PM. Trygve Braatøy og endringer i det moderne menneskebilde. Hovedfagsoppgave i idéhistorie. Oslo: Universitetet i Oslo, 1990. www.aviana.com/per/braatoy/braato04.htm (3.9.2007).

8. Alnæs R. Psykoanalysen i Norge: historie, utdannelse, behandling, forskning. Nord J Psychiatry 1994: 48 (suppl 32): 18-20.

9. Braatøy T. Kjærlighet og åndsliv. Essays. Oslo: Fabritius \& Sønners Forlag, 1934.

Manuskriptet ble mottatt 11.9. 2007 og godkjent 9.3. 2009. Medisinsk redaktør Anne Gitte Hertzberg 